Taxonomy and systematics

\title{
Redescription of Tanaisia dubia (Digenea) from the northeast region of Argentina, with a key to Neotropical species of the genus, and a key to genera of Tanaisiinae
}

\author{
Redescripción de Tanaisia dubia (Digenea) en la región nordeste de Argentina, con una clave de las \\ especies neotropicales del género y una clave de los géneros de Tanaisiinae \\ Lía I. Lunaschi*, Fabiana B. Drago, Regina Draghi \\ División Zoología Invertebrados, Museo de La Plata, Facultad de Ciencias Naturales y Museo, Universidad Nacional de La Plata, Paseo del Bosque S/N, \\ 1900 La Plata, Buenos Aires, Argentina
}

Received 14 January 2015; accepted 12 June 2015

Available online 11 November 2015

\begin{abstract}
Tanaisia dubia Freitas, 1951 (Digenea: Eucotylidae) is redescribed on the basis of specimens collected from the urinary tubules of the Whitebacked Stilt Himantopus melanurus (Charadriiformes: Recurvirostridae), and the Great Kiskadee Pitangus sulphuratus (Passeriformes: Tyrannidae), from Argentina. The specimens studied here are consistent with the original description, which was based on 1 specimen found parasitizing the Gray Yellowlegs Tringa melanoleuca (Charadriiformes, Scolopacidae), from Brazil. This redescription adds new morphological characters and enlarges the range of morphometric data for this species. A key to the genera of Tanaisiinae, as well as one for Neotropical species of Tanaisia Skrjabin, 1924 are presented. The diagnosis of Tanaisiinae is emended to include the presence of a cirrus sac. T. dubia is reported for the first time in Argentina and H. melanurus and P. sulphuratus represent new host records.

All Rights Reserved (C) 2015 Universidad Nacional Autónoma de México, Instituto de Biología. This is an open access item distributed under the Creative Commons CC License BY-NC-ND 4.0.

Keywords: Eucotylidae; Himantopus melanurus; Recurvirostridae; Pitangus sulphuratus; Tyrannidae

\section{Resumen}

Tanaisia dubia Freitas, 1951 (Digenea: Eucotylidae) es redescrita a partir de ejemplares encontrados en los túbulos urinarios del tero real Himantopus melanurus (Charadriiformes: Recurvirostridae) y del benteveo Pitangus sulphuratus (Passeriformes: Tyrannidae) de Argentina. Los especímenes aquí estudiados corresponden con la descripción original, basada en un ejemplar hallado parasitando al pitotoy grande Tringa melanoleuca (Charadriiformes, Scolopacidae), de Brasil. Esta redescripción aporta nuevos caracteres morfológicos y amplía el intervalo de valores morfométricos para esta especie. Se presenta una clave para la identificación de los géneros de Tanaisiinae y otra para las especies neotropicales del género Tanaisia Skrjabin, 1924. La descripción de Tanaisiinae es enmendada para incluir la presencia del saco del cirro. Tanaisia dubia se registra por primera vez para Argentina parasitando 2 especies hospedadoras nuevas, H. melanurus y P. sulphuratus.

Derechos Reservados (C) 2015 Universidad Nacional Autónoma de México, Instituto de Biología. Este es un artículo de acceso abierto distribuido bajo los términos de la Licencia Creative Commons CC BY-NC-ND 4.0.
\end{abstract}

Palabras clave: Eucotylidae; Himantopus melanurus; Recurvirostridae; Pitangus sulphuratus; Tyrannidae

\section{Introduction}

* Corresponding author.

E-mail address: lunaschi@fcnym.unlp.edu.ar (L.I. Lunaschi).

Peer Review under the responsibility of Universidad Nacional Autónoma de México.
The White-backed Stilt, Himantopus melanurus Vieillot (Charadriiformes: Recurvirostridae) - also considered as Himantopus mexicanus melanurus (Remsen et al., 2014) - inhabits marshes, shallow lakes and ponds and is widely distributed in South America, being a well-studied 
species in Argentina. At present, the records for helminth parasites of the White-backed Stilt from South America are represented by Microphallus simillimus (Travassos, 1920), Microphallus szidati Martorelli, 1986, Levinseniella cruzi Travassos, 1920 (Microphallidae); Psilochasmus oxyurus (Creplin, 1825) (Psilostomidae); Pygidiopsis crassus Ostrowski-de Núñez, 1995, Ascocotyle (Ascocotyle) felippei Travassos, 1928 (Heterophyidae), Profilicollis chasmagnathi (Holcman-Spector, Mane-Garzón, \& Dei-Cas, 1977) (as Falsifilicollis ch.) (Polymorphidae) and Davainea himantopodis Johnston, 1911 (Davaineidae) in Argentina; Stomylotrema bijugum Braun, 1901 (Stomylotrematidae) and Tanaisia valida Freitas, 1951 (Eucotylidae) in Brazil; Microsomacanthus kaulobatroni Deblock and Vaucher, 1997, and Wardium neotropicale Deblock and Vaucher, 1997 (Hymenolepididae) in Paraguay (Alda, Martorelli, \& Sarria, 2011; Deblock \& Vaucher, 1997; Martorelli, 1986, 1988, 1989, 1991; Martorelli \& Ivanov, 1996; Tanzola, 1989; Travassos, Freitas, \& Kohn, 1969). The Great Kiskadee, Pitangus sulphuratus (L.) (Passeriformes: Tyrannidae), inhabits open woodlands and is widely distributed in the American continent. The records of parasites for this bird are represented by Neodiplostomum branchiocystis (Lutz, 1928) Dubois, 1937 (Diplostomidae) and Stephanoprora pitangui (Lutz, 1924) (Echinostomatidae) from Brazil and Venezuela; Echinochasmus sulphuratus (Nasir \& Diaz, 1973) in Venezuela; Echinochasmus everardi (Rutledge, Schmidt, \& Tikasingh, 1977) (Echinostomatidae) in Trinidad; Posthodiplostomum nanum Dubois, 1937 (experimental host), Lophosicyadiplostomum nephrocystis (Lutz, 1928) (Diplostomidae), Gynaecotyla adunca (Linton, 1905) (Microphallidae), Diplotriaena delirae Pinto and Noronha, 1970 (Diplotriaenidae), Skrjabinoclava tupacincai Freitas, Vicente, and Ibáñez, 1970, Deliria gomesae Vicente, Pinto, and Noronha, 1980, Dispharynx nasuta (Rudolphi, 1819) (Acuariidae), Thelazia sp. (Thelaziidae), Biuterina campanuiata (Rudolphi, 1819) (Dilepididae) in Brazil; Neodiplostomum fastigatum Dubois, 1985 and Conodiplostomum pitangi (Dubois, 1985) (Diplostomidae) in Paraguay; Austrodiplostomum mordax Szidat and Nani, 1951 (experimental host) (Diplostomidae), and Echinochasmus talaensis Martorelli, 1985 (Echinostomatidae) from Argentina (Caballero \& Díaz-Ungría, 1958; Dubois, 1970, 1985; Martorelli, 1985; Moura Mendes, Mascarenhas, \& Müller, 2011; Muniz-Pereira, Arruda, \& Pinto, 2004; Nasir \& Diaz, 1973; Noronha, Sá, Knoff, Muniz-Pereira, \& Pinto, 2009; Ostrowski-de Núñez, 1968; Rutledge et al., 1977; Travassos et al., 1969; Vicente, Pinto, \& Noronha, 1983a, 1983b).

The aim of this paper is to redescribe Tanaisia dubia Freitas, 1951 (Eucotylidae) harbored by H. melanurus and P. sulphuratus, and to propose a key to the genera of Tanaisiinae Freitas, 1951 and another one for the Neotropical species of Tanaisia Skrjabin, 1924.

\section{Materials and methods}

A single specimen of the White-backed Stilt and another of the Great Kiskadee were captured on August 2013 in La Marcela farm $\left(26^{\circ} 17^{\prime} 35^{\prime \prime} \mathrm{S}, 59^{\circ} 08^{\prime} 38^{\prime \prime} \mathrm{W}\right)$, Pirané, Formosa Province,
Argentina; with authorization of Ministerio de la Producción, Dirección de Fauna y Parques of Formosa Province. The birds were dissected in the field and their viscera analyzed immediately after capture. Digeneans were removed alive, fixed in hot $5 \%$ formalin; some specimens were stained with hydrochloric carmine and mounted in Canada balsam, and others studied in temporary mounts in water, unstained. Drawings were made with the aid of a drawing tube. Measurements are given in micrometers $(\mu \mathrm{m})$ unless otherwise stated, as well as the range followed by the mean in parentheses. The helminths were deposited in the Helminthological Collections of the Museo de La Plata (MLP) and the birds deposited at the Ornithological Collection of the Museo de La Plata (MLP), Argentina. The abbreviations of the metrical features are as follows: Atl, anterior testis length; Atw, anterior testis width; Bl, body length; Bw, body width; Cs, cirrus sac; El, eggs length; Ew, eggs width; Esl, esophagus length; Lpvf, left post-vitelline field; Lv, left vitellarium; Ol, ovary length; Osl, oral sucker length; Osw, oral sucker width; Ow, ovary width; Phl, pharynx length; Phw, pharynx width; Ptl, posterior testis length; Ptw, posterior testis width; Rpvf, right post-vitelline field; Rv, right vitellarium; T, tegument; Vs, ventral sucker.

\section{Redescription}

\section{Tanaisia dubia Freitas, 1951 (Figs. 1-5)}

\section{Diagnosis based on 12 specimens}

Body elongate, flattened, $1.2-2.9 \mathrm{~mm}(2.5 \mathrm{~mm})$ long by 338-657 (528) wide. Tegument with scales throughout entire length of body, clearly visible in temporary preparations; ventral scales in anterior region without teeth; ventral scales in median and posterior regions with 2-5 blunt teeth per scale, exceptionally with 6 blunt teeth. Tegumentary scales 7-13 (9) long by 15-20 (17) wide. Oral sucker subterminal, 107-145 (123) long by 131-193 (167) wide. Oral sucker surface with tegumentary papillae disposed in 1 row of 7 papillae on the ventral surface and 10 pairs in the latero-dorsal surface; these papillae are clearly visible in temporary preparations. Ventral sucker absent. Prepharynx lacking; pharynx 62-97 (64) long by 69-111 (98) wide; esophagus short, 77-106 (87) long, caeca united posteriorly forming cyclocoel. Genital pore median, preovarian, genital atrium large. Cirrus sac small, globular, well developed, with muscular wall, $97 \times 68$; contains seminal vesicle, prostatic cells large, and small cirrus. Testes globular, diagonal, close together, intercaecal, in second fourth of body; anterior testis 107-309 (246) long by 143-338 (237) wide; posterior testis 140-328 (246) long by 119-386 (248) wide. Ovary, intercecal, pretesticular, submedian, on left side of anterior testis, lobed, 121-300 (228) long by 131-319 (233) wide. Seminal receptacle and Mehlis gland, immediately posterior to ovary. Vitellaria follicular, in 2 lateral symmetrical longitudinal bands, asymmetric exceptionally, extending from the level of ovarian region to the third quarter of the body; right vitelline field $0.6-1.4 \mathrm{~mm}$ $(1.1 \mathrm{~mm})$ long, ending at 208-851 (584) from posterior end of body; left vitelline field $0.5-1.3 \mathrm{~mm}(1.0 \mathrm{~mm})$ long, terminating at 280-991 (742) from posterior end of body. Uterus highly 

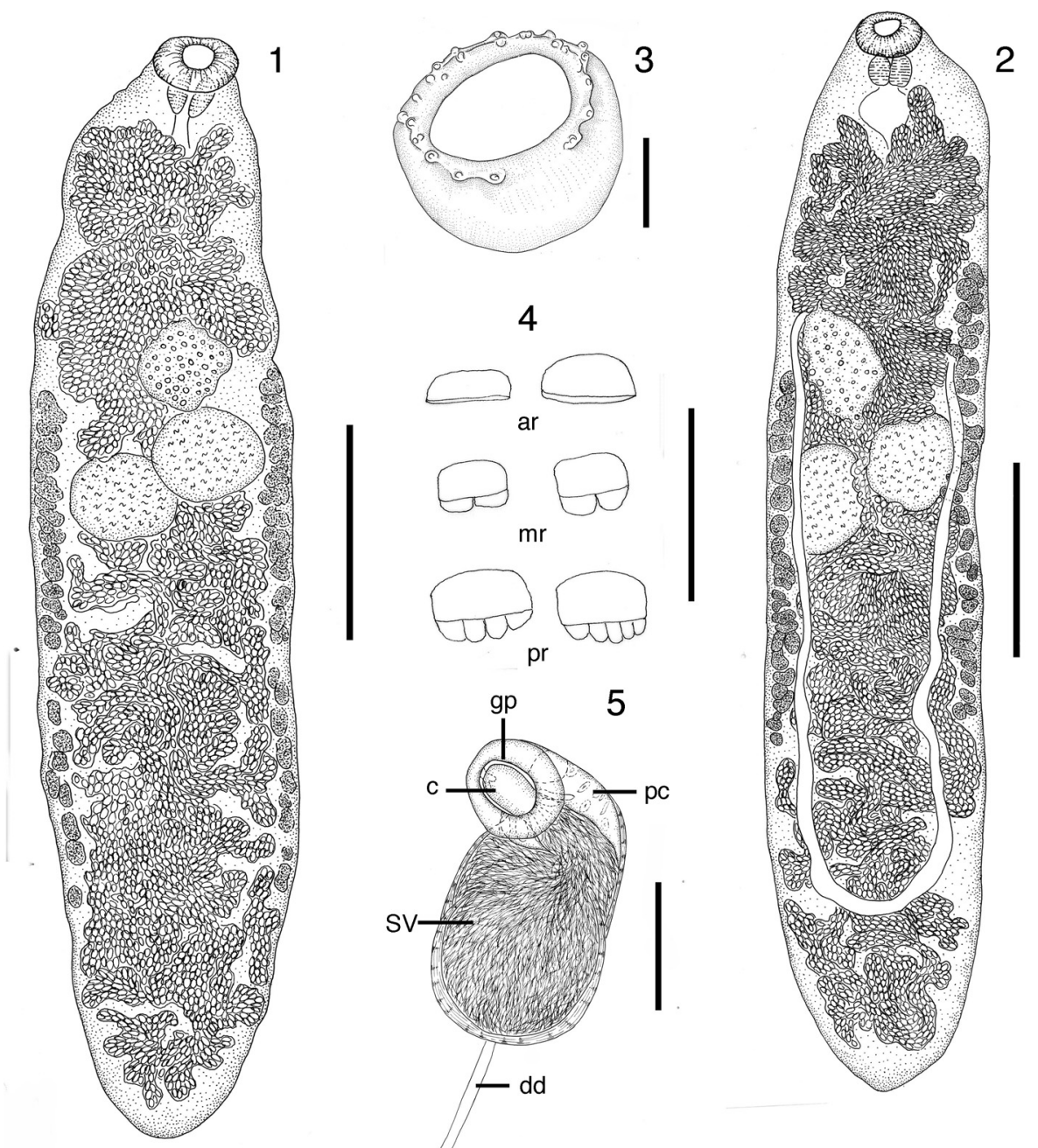

Figures 1-5. Tanaisia dubia from Himantopus melanurus. (1) Specimens with vitelline follicles disposed in 2 symmetrical bands, dorsal view, scale bar $=500 \mu m$. (2) Specimen with vitelline follicles in 2 asymmetrical bands, ventral view, scale bar $=500 \mu \mathrm{m}$. (3) Oral sucker with tegumentary papillae, scale bar $=50 \mu \mathrm{m}$. (4) Tegumental scales, scale bar $=20 \mu \mathrm{m}$. (5) Cirrus sac, scale bar $=50 \mu \mathrm{m}$. ar, scales from anterior region without teeth; c, cirrus; dd, deferent duct; gp, genital pore; $\mathrm{mr}$, scales from midregion with 2 blunt teeth; pc, prostatic cells; pr, scales from posterior region with 4-5 blunt teeth; sv, seminal vesicle.

convoluted; descending uterus crosses the intertesticular field and reaches the posterior region of body; ascending uterus passes through the intertesticular field, overlapping with the descending limb, and fills almost the entire pretesticular region. Metraterm opens into the genital atrium, laterally to the cirrus sac. Mature eggs smooth, dark brown, $26-38 \times 14-19(33 \times 17)$. Excretory vesicle not seen. Excretory pore dorso-subterminal.

\section{Taxonomic summary}

Hosts: H. melanurus Vieillot (Charadriiformes, Recurvirostridae), P. sulphuratus (L.) (Passeriformes, Tyrannidae)

Locality: La Marcela farm $\left(26^{\circ} 17^{\prime} 35^{\prime \prime} \mathrm{S}, 59^{\circ} 08^{\prime} 38^{\prime \prime} \mathrm{W}\right)$, Pirané, Formosa Province, Argentina.

Date of collection: 30 August 2013.

Site of infection: ureters.

Intensity of infection: H. melanurus: 91 specimens from only 1 host captured; $P$. sulphuratus: 10 specimens from only 1 host captured.

Specimens deposited: MLP-He 6771: 7 specimens whole mounted and 51 in 70\% ethanol from H. melanurus; MLP-He 6672: 10 specimens whole mounted from P. sulphuratus.

\section{Remarks}

The genus Tanaisia comprises a large group of Digenea parasitic in urinary tubules of birds from different biogeographical regions. The Tanaisia spp. possess a fairly uniform morphology and are hardly distinguishable from each other. Freitas (1951) considered the presence of spines or scales, as well as their shape, an important specific diagnostic character; Odening (1963) extended this concept for all eucotylid species, however, Rietschel and Werding (1978) observed that in T. valida the scales shape seem to be of little taxonomic value. The specimens described here share the presence of scaly tegument with 11 species reported in the Neotropical region: T. dubia, Tanaisia exigua Freitas, 1951, Tanaisia incerta Freitas, 1951, Tanaisia inopina Freitas, 1951, Tanaisia magnicolica Freitas, 1951, Tanaisia minax Freitas, 1951, Tanaisia oviaspera Freitas, 1951, Tanaisia parva Freitas, 1951, Tanaisia similis Freitas, 1951, T. valida and Tanaisia angusta Franco, 1965. All of these species have similar morphometric characters (Table 1); however, the specimens collected in the White-backed Stilt and the Great Kiskadee possess morphological and morphometric 
Table 1

Measurements of Neotropical species of Tanaisia with scaly tegument.

\begin{tabular}{|c|c|c|c|c|c|c|c|c|}
\hline \multirow{2}{*}{$\begin{array}{l}\text { Species } \\
\text { Source }\end{array}$} & \multicolumn{2}{|c|}{ Tanaisia dubia } & \multirow{2}{*}{\multicolumn{2}{|c|}{$\begin{array}{l}\text { Tanaisia incerta } \\
\text { Freitas } \\
\text { (1951) }\end{array}$}} & Tanaisia inopina & \multirow{2}{*}{$\begin{array}{l}\text { Tanaisia magnicolica } \\
\text { Freitas } \\
\text { (1951) }\end{array}$} & \multirow{2}{*}{$\begin{array}{l}\text { Tanaisia oviaspera } \\
\text { Freitas } \\
\text { (1951) }\end{array}$} & \multirow{2}{*}{$\begin{array}{l}\text { Tanaisia minax } \\
\text { Freitas } \\
(1951)\end{array}$} \\
\hline & Present study & $\begin{array}{l}\text { Freitas } \\
(1951)\end{array}$ & & $\begin{array}{l}\text { Freitas } \\
(1951)\end{array}$ & $\begin{array}{l}\text { Freitas } \\
(1959)\end{array}$ & & & \\
\hline $\mathrm{Bl}(\mathrm{mm})$ & $1.2-2.9$ & 1.54 & $2.28-3.22$ & $1.51-2.04$ & $2.28-3.28$ & $1.09-3.82$ & $2.51-3.01$ & $2.18-3.68$ \\
\hline $\mathrm{Bw}$ & $338-657$ & 390 & $620-770$ & $400-550$ & $570-740$ & $280-830$ & $490-750$ & $540-870$ \\
\hline $\mathrm{T}$ & Scaly & Scaly & Scaly & Scaly & Scaly & Scaly & Scaly & Scaly \\
\hline Osl & $107-145$ & 130 & $180-280$ & $160-220$ & $220-250$ & $120-300$ & $170-200$ & $180-280$ \\
\hline Osw & $131-193$ & 170 & $180-310$ & $170-250$ & $250-310$ & $130-330$ & $190-220$ & $250-330$ \\
\hline Vs & Absent & Not seen & 29-34 & Not seen & Not seen & $20-40 \times 20-50$ & Not seen & $70-100$ \\
\hline Phl & $62-97$ & 94 & $80-100$ & $60-80$ & $80-100$ & $40-100$ & $80-100$ & $70-100$ \\
\hline Phw & $69-111$ & $99-118$ & $100-130$ & $80-100$ & $80-120$ & $50-120$ & $100-120$ & $100-150$ \\
\hline Esl & $77-106$ & - & - & - & - & - & - & - \\
\hline $\mathrm{Cs}$ & $97 \times 68$ & - & - & - & - & - & - & - \\
\hline $\mathrm{Ol}$ & $121-300$ & 110 & $130-180$ & $150-190$ & $130-300$ & $90-360$ & $160-220$ & $140-300$ \\
\hline Ow & $131-319$ & 200 & $170-320$ & $140-280$ & $120-310$ & $120-360$ & $210-260$ & $170-290$ \\
\hline Atl & $107-309$ & 140 & $130-220$ & $130-220$ & $170-310$ & $80-360$ & $130-230$ & $190-330$ \\
\hline Atw & $143-338$ & 160 & $160-260$ & $130-170$ & $150-270$ & $90-390$ & $140-270$ & $80-260$ \\
\hline Ptl & $140-328$ & 150 & $120-260$ & $130-170$ & $180-370$ & $70-330$ & $150-230$ & $130-370$ \\
\hline Ptw & $119-386$ & 140 & $130-190$ & $110-230$ & $130-300$ & $80-300$ & $160-300$ & $70-220$ \\
\hline $\mathrm{Rv}(\mathrm{mm})$ & $0.6-1.4$ & 0.6 & $0.7-1.24$ & $0.5-1.0$ & $0.65-1.1$ & $0.37-1.51$ & $0.8-1.27$ & $0.65-1.34$ \\
\hline Rpvf (mm) & $0.21-0.85$ & 0.3 & $0.6-1.06$ & $0.36-0.46$ & $0.4-1.0$ & $0.33-1.24$ & $0.57-1.0$ & $0.53-1.31$ \\
\hline $\mathrm{Lv}(\mathrm{mm})$ & $0.5-1.3$ & 0.67 & $0.83-1.33$ & $0.6-0.83$ & $0.77-1.17$ & $0.37-1.61$ & $0.94-1.31$ & $0.75-1.49$ \\
\hline Lpvf (mm) & $0.28-0.99$ & 0.4 & $0.68-1.08$ & $0.33-0.48$ & $0.3-1.04$ & $0.33-1.27$ & $0.57-0.9$ & $0.93-1.08$ \\
\hline El & $26-38$ & $35-42$ & $34-40$ & $34-38$ & $34-38$ & $30-42$ & $34-35$ & $44-52$ \\
\hline Ew & 14-19 & $13-15$ & $20-23$ & $14-16$ & $16-17$ & $13-19$ & $16-19$ & $21-27$ \\
\hline Species & Tanaisia similis & & & Tanaisia valida & & Tanaisia parva & Tanaisia exigua & Tanaisia angusta \\
\hline Source & Freitas (1951) & Freitas (195 & & $\begin{array}{l}\text { Ibañez-Herrera } \\
\text { (1965) }\end{array}$ & $\begin{array}{l}\text { Rietschel and } \\
\text { Werding (1978) }\end{array}$ & Freitas (1951) & Freitas (1951) & Franco (1965) \\
\hline $\mathrm{Bl}(\mathrm{mm})$ & $1.57-1.94$ & $3.11-3.45$ & & $2.67-4$ & $3.3-3.8$ & 3.62 & 2.95 & 3.93 \\
\hline $\mathrm{Bw}$ & $540-600$ & $890-940$ & & $600-780$ & $705-780$ & 770 & 430 & 670 \\
\hline $\mathrm{T}$ & Scaly & Scaly & & - & Scaly & Scaly & Scaly & Scaly \\
\hline Osl & $100-200$ & $180-230$ & & $133-233$ & $169-235$ & $220^{\circ}$ & 220 & 180 \\
\hline Osw & $200-250$ & $200-250$ & & $180-280$ & $195-282$ & 230 & & 200 \\
\hline Vs & Not seen & Not seen & & Not seen & Not seen & Not seen & Not seen & Not seen \\
\hline Phl & $70-100$ & $50-80$ & & $65-100$ & 94 & 80 & 80 & 80 \\
\hline Phw & $80-100$ & $80-90$ & & $100-120$ & $99-118$ & 90 & 100 & 90 \\
\hline Esl & - & - & & - & - & & - & - \\
\hline Cs & - & - & & $67-133 \times 47-80$ & - & - & - & - \\
\hline $\mathrm{Ol}$ & $130-200$ & $200-270$ & & $150-333$ & $210-329$ & 360 & 280 & 270 \\
\hline Ow & $160-230$ & $230-310$ & & $167-233$ & $306-329$ & 410 & 220 & 380 \\
\hline Atl & $130-200$ & $170-280$ & & $200-333$ & $282-235$ & 360 & 160 & 160 \\
\hline Atw & $140-220$ & $250-310$ & & $217-333$ & $235-329$ & 350 & 130 & 90 \\
\hline Ptl & $130-230$ & $230-280$ & & $183-367$ & $235-282$ & 420 & 110 & 100 \\
\hline Ptw & $160-210$ & $220-300$ & & $167-250$ & $259-329$ & 260 & 130 & 110 \\
\hline $\mathrm{Rv}(\mathrm{mm})$ & $0.56-0.8$ & $1.47-1.74$ & & $1.33-2.03$ & - & 1.51 & 0.86 & 2.08 \\
\hline Rpvf (mm) & $0.5-0.53$ & $0.6-0.9$ & & $0.8-1.2$ & - & 1.07 & 1.13 & 0.67 \\
\hline $\mathrm{Lv}(\mathrm{mm})$ & $0.66-0.75$ & $1.44-1.91$ & & $1.07-1.47$ & - & - & 0.86 & 3.26 \\
\hline Lpvf (mm) & 0.56 & $0.54-0.74$ & & $1.07-1.71$ & - & - & 1.13 & 0.41 \\
\hline $\mathrm{El}$ & $34-36$ & $31-34$ & & 33 & $31-34$ & $31-38$ & $34-38$ & 33 \\
\hline Ew & $17-18$ & $13-17$ & & 14 & $11-13$ & $17-19$ & $14-15$ & $13-15$ \\
\hline
\end{tabular}

features similar to the specimen described by Freitas (1951) as T. dubia. The description of this species was based on 1 poorly preserved young specimen from the Greater Yellowlegs, Tringa melanoleuca (Gmelin) (Scolopacidae) from Zoological Garden of Rio de Janeiro, Brazil. The new morphometrical data, the presence of tegumentary papillae on the oral sucker surface, the confirmation of the absence of a ventral sucker (originally described as not visible), the morphological variation of the scales along the worm body, the conformation of the cirrus sac, and position of the excretory pore, make it possible to supplement the original description.

To date, only 2 species of Tanaisia has been reported in Argentina, Tanaisia serrata Szidat, 1961 found parasitizing the White-winged Coot, Fulica leucoptera Vieillot (Gruiformes: Rallidae) from Quequén River, Buenos Aires Province, and Tanaisia fedtschenkoi Skrjabin, 1924 in Chroicocephalus maculipennis (Lichtenstein) and Chroicocephalus cirrocephalus (Vieillot) from Mar del Plata, Buenos Aires Province 
Table 2

List of definitive host species and country for Neotropical Tanaisia spp.

\begin{tabular}{|c|c|c|c|c|}
\hline Species & Host family & Host species & Country & Reference \\
\hline T. angusta & Rallidae & Pardirallus maculatus maculatus & Brazil & Franco (1965), Travassos et al. (1969) \\
\hline \multirow[t]{3}{*}{ T. dubia } & Scolopacidae & Tringa melanoleuca & Brazil & Freitas (1951), Travassos et al. (1969) \\
\hline & Recurvirostridae & Himantopus melanurus & Argentina & Present study \\
\hline & Tyrannidae & Pitangus sulphuratus & Argentina & Present study \\
\hline T. exigua & Troglodytidae & Troglodytes musculus musculus & Brazil & Freitas (1951), Travassos et al. (1969) \\
\hline \multirow{3}{*}{ T. fedtschenkoi } & Scolopacidae & Tringa melanoleuca & Venezuela & McNeil, Díaz, Casanova, and Villeneuve (1996) \\
\hline & Laridae & Chroicocephalus maculipennis & Argentina & Labriola and Suriano (2001) \\
\hline & & Chroicocephalus cirrocephalus & Argentina & Labriola and Suriano (2001) \\
\hline T. freitasi & Icteridae & Psarocolius montezuma & Costa Rica & $\begin{array}{l}\text { Brenes and Arroyo (1962); Rodríguez-Ortíz, García-Prieto, } \\
\text { and Pérez-Ponce de León (2004) }\end{array}$ \\
\hline T. incerta & Emberizidae & Ammodramus humeralis humeralis & Brazil & Freitas (1951) \\
\hline \multirow[t]{6}{*}{ T. inopina } & Passeridae & Passer domesticus & Brazil & Freitas (1951); Brasil and Amato (1992) \\
\hline & Turdidae & Turdus rufiventris & Brazil & Calegaro-Marques and Amato (2010) \\
\hline & Laridae & Sterna sp. & Brazil & Freitas $(1951,1959)$ \\
\hline & Icteridae & Icterus chrysocephalus & Brazil & Franco (1965) \\
\hline & Phasianidae & Coturnix japonica & Brazil & Pinto, Menezes, and Tortelly (2005) \\
\hline & Columbidae & Columba livia & Brazil & D’ávila, Manso, Bessa, Rodrigues, and Días (2010) \\
\hline \multirow[t]{4}{*}{ T. magnicolica } & Cuculidae & Guira guira & Brazil & Freitas (1951) \\
\hline & Emberizidae & Paroaria capitata & Brazil & Freitas (1951) \\
\hline & Columbidae & Columbina talpacoti talpacoti & Brazil & Queiróz (1966); Travassos et al. (1969) \\
\hline & & Psophia viridis obscura & Brazil & Muniz-Pereira, Vieira, and Luque (2009) \\
\hline \multirow[t]{3}{*}{ T. minax } & Corvidae & Cyanocorax cyanomelas & Brazil & Freitas (1951) \\
\hline & Passeridae & Cyanocorax chysops & Brazil & Freitas (1951) \\
\hline & & Passer domesticus & Brazil & Freitas (1951) \\
\hline \multirow{7}{*}{ T. oviaspera } & Thraupidae & Ramphocelus c. connectens & Brazil & Freitas (1951) \\
\hline & Icteridae & Ramphocelus carbo carbo & Brazil & Freitas (1951) \\
\hline & Emberizidae & Thraupis sayaca sayaca & Brazil & Freitas (1951) \\
\hline & & Tangara seledon & Brazil & Odening (1963) \\
\hline & & Dacnis cayana & Brazil & Odening (1970) \\
\hline & & Icterus pyrrhopterus & Brazil & Freitas (1951) \\
\hline & & Paroaria coronata & Brazil & Mascarenhas, Krüger, and Müller (2009) \\
\hline T. parva & Corvidae & Cyanocorax cristatellus & Brazil & Freitas (1951), Travassos et al. (1969) \\
\hline T. precaria & Strigidae & Speotyto cunicularia grallaria & Brazil & Freitas (1951), Travassos et al. (1969) \\
\hline T. serrata & Rallidae & Fulica leucoptera & Argentina & Szidat, 1961 \\
\hline T. similis & Corvidae & Cyanocorax chysops & Brazil & Freitas (1951) \\
\hline \multirow[t]{5}{*}{ T. valida } & Recurvirostridae & Himantopus melanurus & Brazil, & Freitas (1951), \\
\hline & & & Perú & Ibañez-Herrera $(1965,1998)$ \\
\hline & Scolopacidae & Phalaropus tricolor & Perú & Tantalean, Sarmiento, and Huiza (1992) \\
\hline & Emberizidae & Paroaria coronata & Brazil & Ibañez-Herrera (1965); Tantalean et al. (1992) \\
\hline & Charadriidae & Charadrius wilsonia & Colombia & Mascarenhas et al. (2009), Rietschel and Werding (1978) \\
\hline T. winteri & Jacanidae & Jacana spinosa spinosa & Costa Rica & Brenes and Arroyo (1962); Rodríguez-Ortíz et al. (2004) \\
\hline
\end{tabular}

(Labriola \& Suriano, 2001; Szidat, 1961). The present finding represents the first record of $T$. dubia since its original description and the first for Argentina, and H. melanurus and $P$. sulphuratus constitute new hosts records for this species.

\section{Discussion}

Freitas (1951) erected the subfamily Tanaisiinae and described 13 species of Tanaisia found parasitizing Neotropical birds. According to Freitas (1959) and Kanev, Radev, and Fried (2002) only 11 remain as valid species. Later, another 4 species were described in the Neotropical region: T. serrata from Argentina, Tanaisia winteri Brenes and Arroyo, 1962 and Tanaisia freitasi Brenes and Arroyo, 1962 from Costa Rica, and T. angusta from Brazil (Brenes \& Arroyo, 1962; Franco, 1965; Szidat, 1961). Odening (1963) described a new species, Tanaisia freitasiana Odening, 1963, which was later synonymized with $T$. oviaspera by Odening (1970). Freitas
(1951) and Odening (1963) highlighted the need of a detailed study of the tegument for identification of the eucotylid species. The tegument of this species may have comb-like scales or simple spines; which rarely may be absent, or only vestigial in older specimens.

The diagnosis of Tanaisia given by Freitas (1951) includes species with testes in tandem, diagonal or symmetrical, which were described as "testículos na mesma zona ou em zonas que coincidem parcialmente, ou, ainda, no mesmo campo". Kanev et al. (2002) characterize this genus with testes in tandem or diagonal to differentiate it from the other members of the subfamily with similar organization, but with symmetrical testes: Paratanaisia Freitas, 1959 and Tamerlania Skrjabin, 1924. Moreover, these genera differ primarily in the extension of vitelline fields; Tanaisia with vitelline fields only in postovarian region, Paratanaisia with vitelline fields extending in both preovarian and postovarian regions, and Tamerlania with vitelline fields restricted to post-testicular region. 
Key to genera Tanaisiinae Freitas, 1951.

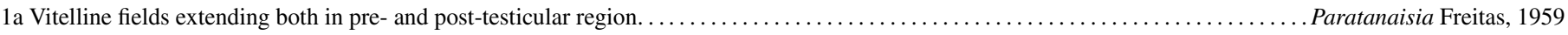
$1 \mathrm{~b}$ Vitelline fields from ovarian or post-testicular region.

Tamerlania was synonymized with Tanaisia by Freitas (1951, 1959), considered as subgenus of Tanaisia by Yamaguti (1958, 1971) and recognized as valid genus by Kanev et al. (2002). We have analyzed the descriptions and drawings of the species described by Freitas (1951), Brenes and Arroyo (1962) and Franco (1965), and observed that 10 Neotropical species exhibit intermediate characters between Tanaisia and Tamerlania, possessing testes symmetrical, irregular in shape or slightly lobed, and vitelline fields not restricted to post-testicular region. We believe that the most important morphological feature to distinguish the 3 genus of Tanaisiinae is the extension of vitelline fields. For this reason, we propose the following key for the subfamily.

The results of this study indicate that Tanaisia should also include species with symmetrical testes and vitelline fields beginning at the ovarian or postovarian regions, and consequently should be retain the original names for Tanaisia precaria Freitas, 1951, T. minax, T. magnicolica, T. incerta, T. oviaspera, T. inopina, T. similis, T. exigua, T. parva, and T. valida. We provide a key to facilitate differentiation of the species of Tanaisia.

Key to species of Tanaisia Skrjabin, 1924 from Neotropical region.

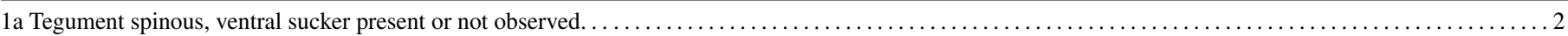

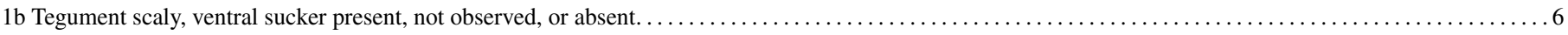

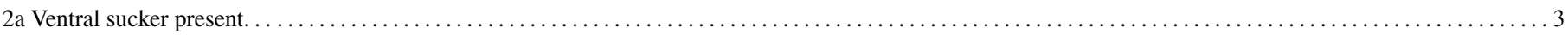

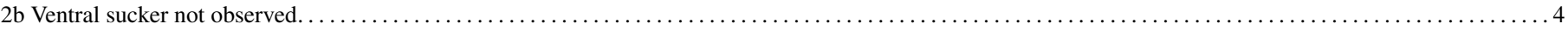

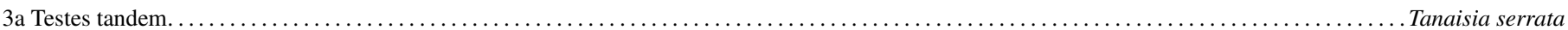

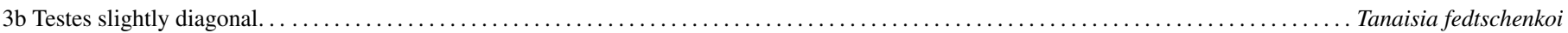

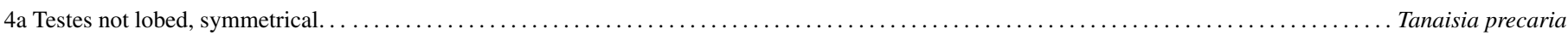

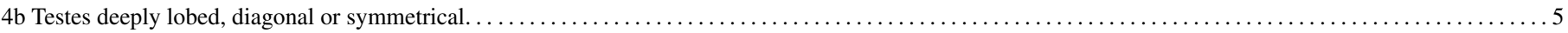

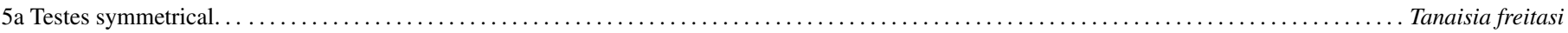

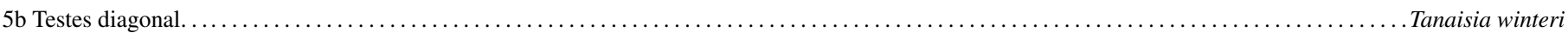

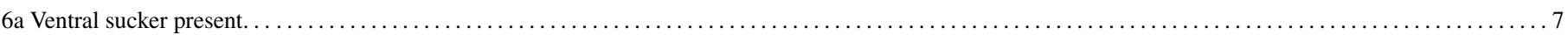

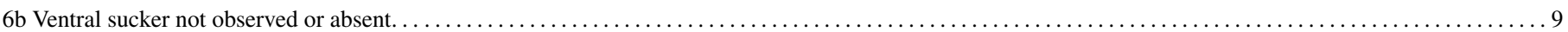

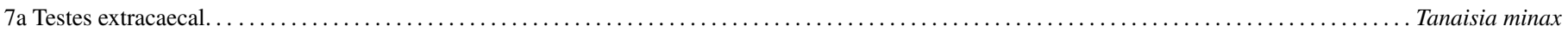

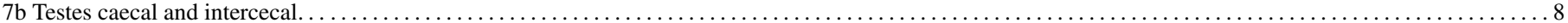

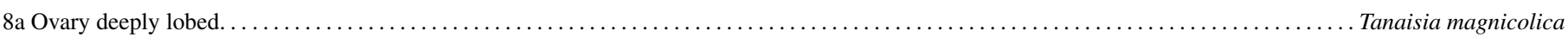

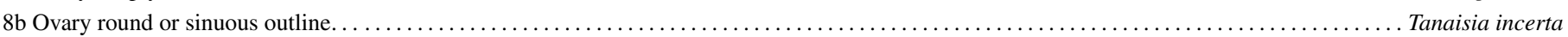

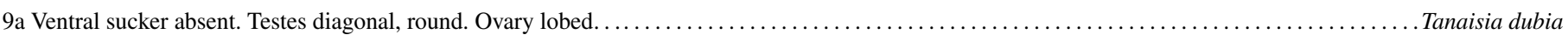

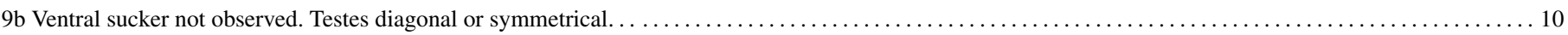

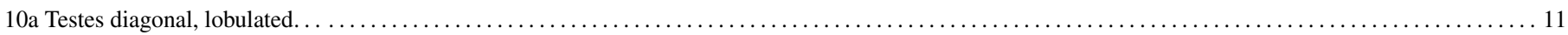

10b Testes symmetrical . . . . . . . . .

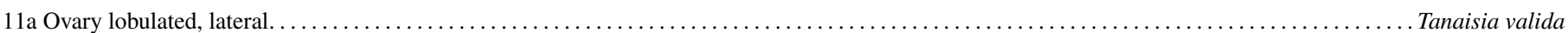

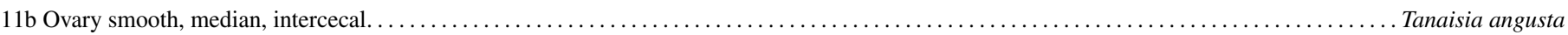

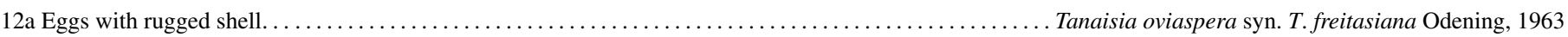

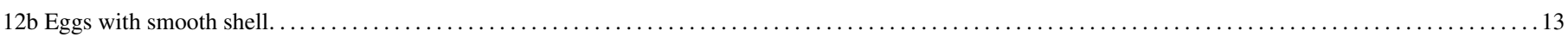

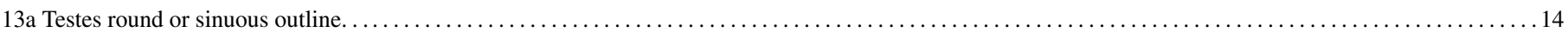

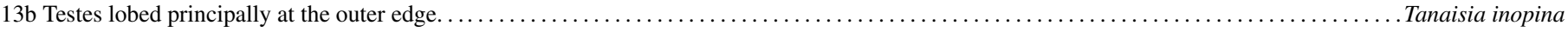

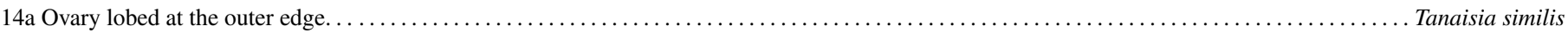

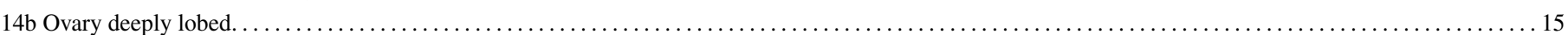

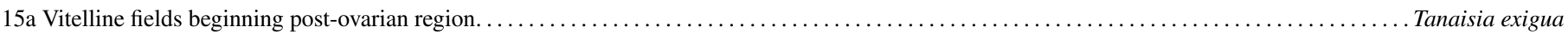

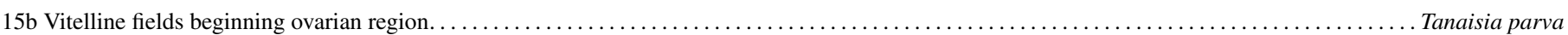


A total of 16 species of Tanaisia parasitize Passeriformes, Charadriiformes, Strigiformes, Galliformes, Gruiformes, Cuculiformes, and Columbiformes from the Neotropical region (Table 2). Particularly, T. dubia was recovered in Charadriiformes (T. melanoleuca and $H$. melanurus) and Passeriformes ( $P$. sulphuratus), only 1 specimen was found in T. melanoleuca by Freitas (1951), whereas in the present study 91 and 10 specimens were found in $H$. melanurus and $P$. sulphuratus, respectively. This could be related with the life cycles of parasites and the diet of birds. The life cycle of $T$. dubia is unknown; however, considering the life cycle pattern of Tanaisiinae, the birds could be infected by ingesting pulmonate gastropods infected with metacercariae. The diet of H. melanurus includes insects, bivalves, gastropods, oligochaetes, polychaetes, tadpoles and small fishes (del Hoyo, Elliot, \& Sargatal, 1996); P. sulphuratus is an omnivorous bird, with a wide spectrum of prey, it feeds on seeds, fruits, insects, arachnids, crustaceans, gastropods, fishes, tadpoles and reptiles (Latino \& Beltzer, 1999); T. melanoleuca primarily eats crustaceans, aquatic and terrestrial insects, worms and small fish (del Hoyo et al., 1996). Given that usually T. melanoleuca does not feed on snails, the presence of T. dubia in this bird could be accidental and more frequent in birds with a diet that includes snails.

Finally, we believe that the diagnosis of Tanaisiinae by Kanev et al. (2002) should be emended to include the presence of a cirrus sac, given that Freitas (1951) described its presence (reduced to seminal vesicle) for all eucotylid species, and is confirmed in the present paper.

\section{Acknowledgements}

The authors express their gratitude to Dr. Carlos Montoya for his help and hospitality during our stay in Formosa Province; to Luis Pagano (Sección Ornitología División Zoología Vertebrados, Museo de La Plata) for assistance in collecting and identification of bird hosts; to Gabriel Baloriani who made the drawings. The present study was funded by CIC (Res. No. 243/13) and UNLP (11/N603).

\section{References}

Alda, M. P., Martorelli, S. R., \& Sarria, R. (2011). Digenean parasites in the White-backed Stilt Himantopus melanurus Vieillot, 1817 (Recurvirostridae) from the Argentine Coast. Comparative Parasitology, 78, 217-219.

Brasil, M. C., \& Amato, S. B. (1992). Faunistic analysis of the helminths of sparrows (Passer domesticus L, 1758) captured in Campo Grande, Rio de Janeiro, R.J. Memórias do Instituto Oswaldo Cruz, 87, 43-48.

Brenes, R. R., \& Arroyo, G. (1962). Helmintos de la República de Costa Rica XX. Algunos tremátodos de aves silvestres. Revista de Biología Tropical, 10, 205-227.

Caballero, E., \& Díaz-Ungría, C. (1958). Intento de un catálogo de los trematodos digéneos registrados en territorio venezolano. Memoria de la Sociedad de Ciencias Naturales La Salle, 18, 19-36.

Calegaro-Marques, C., \& Amato, S. B. (2010). Parasites as secret files of the trophic interactions of hosts: the case of the rufous-bellied thrush. Revista Mexicana de Biodiversidad, 81, 801-811.

D’ávila, S., Manso, P. P. A., Bessa, E. C. A., Rodrigues, M. L. A., \& Días, R. J. P. (2010). Gross anatomy of the musculature and a new description of the reproductive system of Tanaisia bragai and Tanaisia inopina
(Trematoda: Eucotylidae) analysed by confocal laser scanning microscopy. Acta Zoologica, 91, 139-149.

Deblock, S., \& Vaucher, C. (1997). Microsomacanthus kaulobatroni n. sp. et Wardium neotropicale $\mathrm{n}$. sp. parasites d' Himantopus melanurus du Paraguay. Systematic Parasitology, 37, 127-138.

del Hoyo, J., Elliot, A., \& Sargatal, J. (1996). . Handbook of the birds of the world (Vol. 3) Barcelona: Lynx.

Dubois, G. (1970). Les Strigeata (Trematoda) de la collection A. Lutz. Memórias do Instituto Oswaldo Cruz, 68, 169-196.

Dubois, G. (1985). Quelques Strigeoidea (Trematoda) récoltés chez des oiseaux du Paraguay par la Mission Claude Weber, automne 1983, du Muséum d'Histoire naturelle de Gèneve. Revue Suisse de Zoologie, 92, 641-648.

Franco, S. R. N. (1965). Nota sôbre trematódeos eucotilídeos (Trematoda, Eucotylidae). Memórias do Instituto Oswaldo Cruz, 63, 59-65.

Freitas, J. F. T. (1951). Revisão da familia Eucotylidae Skrjabin, 1924 (Trematoda). Memórias do Instituto Oswaldo Cruz, 49, 33-271.

Freitas, J. F. T. (1959). Nota sabre Tanaisia inopina Freitas, 1951 (Trematoda, Eucotylidae). Atas da Sociedade de Biologia do Rio de Janeiro, 3, 2-4.

Ibañez-Herrera, N. (1965). Occorencia de Tanaisia valida Freitas, 1951 no Peru (Eucotylidae). Atas Sociedade de Biologia do Rio de Janeiro, 9, $110-112$

Ibañez-Herrera, N. (1998). Mención de algunos tremátodos en la fauna helmintológica peruana. Revista Peruana de Parasitología, 13, 90-97.

Kanev, I., Radev, V., \& Fried, B. (2002). Family Eucotylidae Cohn, 1904. In D. I. Gibson, A. Jones, \& R. A. Bray (Eds.), Keys to the Trematoda (Vol. 1) (pp. 147-152). London: CAB International.

Labriola, J. B., \& Suriano, D. M. (2001). Community structure of parasitic helminths of birds of the genus Larus from Mar del Plata, Argentina. Vie et Milieu, 51, 67-76.

Latino, S., \& Beltzer, A. (1999). Ecología trófica del benteveo Pitangus sulphuratus (Aves: Tyrannidae) en el valle de inundación del río Paraná, Argentina. Orsis, 14, 69-78.

Martorelli, S. R. (1985). Estudios parasitológicos en biotopos lénticos de la República Argentina I: el ciclo biológico de Echinochasmus talaensis sp. nov. (Digenea) parásito de Pitangus sulphuratus bolivianus (Aves, Tyrannidae). Neotropica, 31, 187-200.

Martorelli, S. R. (1986). Estudio sistemático y biológico de un digéneo perteneciente a la familia Microphallidae Travassos, 1920. I: Microphallus szidati sp.nov. parásito intestinal de Rallus sanguinolentus sanguinolentus (Aves, Rallidae) e Himantopus melanurus (Aves, Recurvirostridae). Revista Ibérica de Parasitología, 46, 373-378.

Martorelli, S. R. (1988). El ciclo biológico de Levinseniella cruzi Travassos, 1920 (Digenea, Microphallidae) parásita de los ciegos cólicos de Rollandia rolland chilensis (Aves, Podicipedidae) e Himantopus melanurus (Aves, Recurvirostridae). Iheringia, 68, 49-62.

Martorelli, S. R. (1989). El rol de Cyrtograpsus angulatus (Crustacea; Brachyura) en los ciclos de vida de Microphallus szidati (Gigenea; Microphallidae) y Falsifillcollis chasmagnathi (Acanthocephala; Filicollidae). Algunos aspectos de su ecología parasitaria. Memórias do Instituto Oswaldo Cruz, 84, 567-574.

Martorelli, S. R. (1991). El ciclo biológico abreviado de Microphallus simillimus (Travassos, 1920) comb.n. (Digenea: Microphallidae) parásito de Heleobia conexa (Molusca, Hydrobiidae) y de Himantopus melanurus (Aves, Recurvirostridae) en Argentina. Iheringia, 71, 91-98.

Martorelli, S. R., \& Ivanov, V. A. (1996). Host-Induced and geographical variation in Levinseniella cruzi Travassos, 1920 (Digenea: Microphallidae). Journal of the Helminthological Society of Washington, 63, 130-135.

Mascarenhas, C. S., Krüger, C., \& Müller, G. (2009). The helminth fauna of the red-crested cardinal (Paroaria coronata) Passeriformes: Emberizidae in Brazil. Parasitology Research, 105, 1359-1363.

McNeil, R., Díaz, M. T., Casanova, B., \& Villeneuve, A. (1996). Trematode parasitism as a possible factor in over-summering of Greater Yellowlegs (Tringa melanoleuca). Ornitología Neotropical, 6, 57-65.

Moura Mendes, M., Mascarenhas, C. S., \& Müller, G. (2011). Pitangus sulphuratus (Passeriforme: Tyrannidae) novo hospedeiro para Dispharynx nasuta (Spirurida: Acuariidae). Biomédica, 31, 322.

Muniz-Pereira, L. C., Arruda, V. S., \& Pinto, R. M. (2004). Confirmação da sinonímia de Gynaecotyla jaegerskioeldi (Travassos) (Digenea, 
Microphallidae) com Gynaecotyla adunca (Linton) (Digenea, Gynaecotylinae). Revista Brasileira de Zoologia, 21, 801-804.

Muniz-Pereira, L. C., Vieira, F. M., \& Luque, J. L. (2009). Checklist of helminth parasites of threatened vertebrate species from Brazil. Zootaxa, 2123, 1-45.

Nasir, P., \& Diaz, M. T. (1973). Avian fluke, Episthmium sulphuratus n. sp., from Venezuela. Caribbean Journal of Science, 13, 51-55.

Noronha, D., Sá, M. R., Knoff, M., Muniz-Pereira, L. C., \& Pinto, R. M. (2009). Adolpho Lutz e a Coleção Helmintológica do Instituto Oswaldo Cruz. Rio de Janeiro: Museu Nacional.

Odening, K. (1963). Zwei neue Nierentrematoden der Unterordnung Eucotylata (Digenea, Sporocystoinei) aus Singvögeln Brasiliens und Vietnams. Zeitschrift für Parasitenkunde, 23, 491-503.

Odening, K. (1970). Neue wirte aus Lateinamerika und Südasien für einige vogeltrematoden. Anales del Instituto de Biología, Universidad Nacional Autónoma de México, Serie Zoología, 41, 109-119.

Ostrowski-de Núñez, M. (1968). Sobre el ciclo biológico de Austrodiplostomum mordax Szidat y Nani, 1951. Neotropica, 14, 85-88.

Pinto, R. M., Menezes, R. C., \& Tortelly, R. (2005). Systematic and pathologic study of Paratanaisia bragai (Santos, 1934) Freitas, 1959 (Digenea, Eucotylidae) infestation in ruddy ground dove Columbina talpacoti (Temminck, 1811). Arquivo Brasileiro de Medicina Veterinária e Zootecnia, 56 , $472-479$.

Queiróz, M. A. (1966). Ocorrência de Tanaisia magnicolica Freitas, 1951 (Trematoda, Eucotylidae) em rolinha, no Rio de Janeiro. Atas da Sociedade de Biologia do Rio de Janeiro, 10, 117-118.

Remsen, J. V., Jr., Cadena, C. D., Jaramillo, A., Nores, M., Pacheco, J. F., Pérez-Emán, J., et al. (2014). A classification of the bird species of South America. American Ornithologists' Union., http://www.museum. lsu.edu/ Remsen/SACCBaseline.html, last accessed: 13.VIII.2014.
Rietschel, G., \& Werding, B. (1978). Trematodes of birds from Northern Columbia. Zeitschrift für Parasitenkunde, 57, 57-82.

Rodríguez-Ortíz, B., García-Prieto, L., \& Pérez-Ponce de León, G. (2004). Checklist of the helminth parasites of vertebrates in Costa Rica. Revista de Biología Tropical, 52, 313-354.

Rutledge, T. A., Schmidt, G. D., \& Tikasingh, E. S. (1977). Episthmium everardi sp.n. (Trematoda: Echinostomatidae) from a great kiskadee, Pitangus sulfuratus, in Trinidad. Journal of Helminthology, 51, 313-315.

Szidat, L. (1961). Tanaisia serrata sp. nov. (Trematoda, Eucotylidae) parasito del riñón de Fulica leucoptera Vieill. Neotropica, 7, 65-70.

Tantalean, M., Sarmiento, L. B., \& Huiza, A. F. (1992). Digeneos (Trematoda) del Perú. Boletín de Lima, 80, 47-84.

Tanzola, R. D. (1989). Davainea himantopodis Johnston, 1911 (Eucestoda; Davaineidae) parásito del tero real Himantopus melanurus Vieillot, $18 \mathrm{H}$ (Aves; Recurvirostridae), en la región Neotropical. Studies on Neotropical Fauna and Environmen, 24, 9-13.

Travassos, L., Freitas, J. F. T., \& Kohn, A. (1969). Trematódeos do Brasil. Memórias do Instituto Oswaldo Cruz, 69, 1-886.

Vicente, J., Pinto, R. M., \& Noronha, D. (1983a). Estudo das especies brasileiras do genero Diplotriaena Henry et Ozoux, 1909 (Nematoda, Filarioidea). Memórias do Instituto Oswaldo Cruz, 78, 165-182.

Vicente, J., Pinto, R. M., \& Noronha, D. (1983b). Skrjabinoclava tupacincai Freitas, Vicente and Ibañez, 1970 in Brazil and some other helminths from Tyrannidae birds. Memórias do Instituto Oswaldo Cruz, 78, 95-100.

Yamaguti, S. (1958). Systema helminthum. Part I. The digenetic trematodes of vertebrates. New York: Interscience Publishers.

Yamaguti, S. (1971). Synopsis of digenetic trematodes of vertebrates. Tokyo: Keigaku Publishing. 